\title{
Effects of medications and laser on induced tooth movement and associated root resorption: Four key points
}

\author{
Alberto Consolaro
}

The following four fundamental points on the use of experimental models will be described to ensure an accurate evaluation of the effects of medication and laser therapy on induced tooth movement and associated root resorption: (1) If the objective is to check the effect on root resorption, the forces experimentally applied must produce a lesion on the cementoblast layer in all specimens; (2) If the objective is to optimize induced tooth movement and reduce treatment time without side effects, the forces experimentally applied should not produce a lesion in the cementoblast layer in any specimen; (3) The laser therapy operator, the person administering medication and the person that places appliances should not know which animals will effectively receive the test treatment, and the control groups should receive placebo treatments; (4) CT and microscopic analysis of the specimens should be random, and the group to which the specimen belongs should not be identified to ensure that the person reading images and the pathologists are not influenced in their evaluation of phenomena. These measures will ensure that results are more reliable and easier to extrapolate to orthodontic clinical practice.

Keywords: Induced tooth movement. Root resorption. Tooth resorption. Laser therapy. Medication

Para que a avaliação dos efeitos de medicamentos e da fototerapia na movimentação dentária induzida e reabsorções radiculares associadas seja livre de influências externas, propusemos quatro pontos fundamentais na aplicação dos modelos experimentais: 1) Se o objetivo for verificar a influência nas reabsorções radiculares, deve-se garantir que as forças aplicadas experimentalmente lesem a camada cementoblástica em todos os espécimes; 2) Se o objetivo for otimizar a movimentação dentária induzida reduzindo o tempo de tratamento sem efeitos colaterais, deve-se garantir que as forças aplicadas experimentalmente não irão lesar a camada cementoblástica em nenhum dos espécimes; 3) $\mathrm{O}$ aplicador da fototerapia e/ou do medicamento e o colocador dos aparelhos nos dentes não devem saber quais animais receberão efetivamente o tratamento-teste, e os grupos controle devem receber tratamentos simuladores; 4) As análises tomográfica e microscópica dos espécimes devem ser aleatórias, sem que os espécimes sejam identificáveis quanto ao grupo a que pertencem, para que os imaginologistas e patologistas não sofram qualquer influência na avaliação dos fenômenos. Esses cuidados, se adotados, oferecerão resultados cada vez mais confiáveis e extrapoláveis para a clínica ortodôntica.

Palavras-chave: Movimentação dentária induzida. Reabsorções radiculares. Reabsorções dentárias. Fototerapia. Medicamentos.

Root resorption during orthodontic treatment is a frequent phenomenon, but should not be considered normal or physiological. In numerous clinical cases of orthodontic treatment, apical root resorption is practically inevitable, although predictable when predictive factors are carefully defined. ${ }^{2}$

Although predictive factors are used for analysis, treatment planning often indicates a very high probability of root resorption, which, in such cases, is in${ }^{1}$ Full Professor, FOB-USP. Full Professor of the Post-graduation program,
FORP-USP.

" The author reports no commercial, proprietary or financial interest in the products or companies described in this article. evitable and, as long as predicted and explained to the patient, should not be classified as iatrogenic, as it is the biological cost to pay for the esthetic and functional benefits of orthodontic treatment.

Studies have sought ways to speed up tooth movement and reduce orthodontic treatment time. Several factors have been investigated to find ways to reduce the frequency and severity of root resorption during orthodontic treatment. In this search, medi-

How to cite this article: Consolaro A. Effects of medications and laser on induced tooth movement and associated root resorption: Four key points. Dental Press J Orthod. 2013 Mar-Apr;18(2):4-7.

Submitted: February 28, 2013

Revised and accepted: March 10, 2013

Contact address: Alberto Consolaro

E-mail: consolaro@uol.com.br 


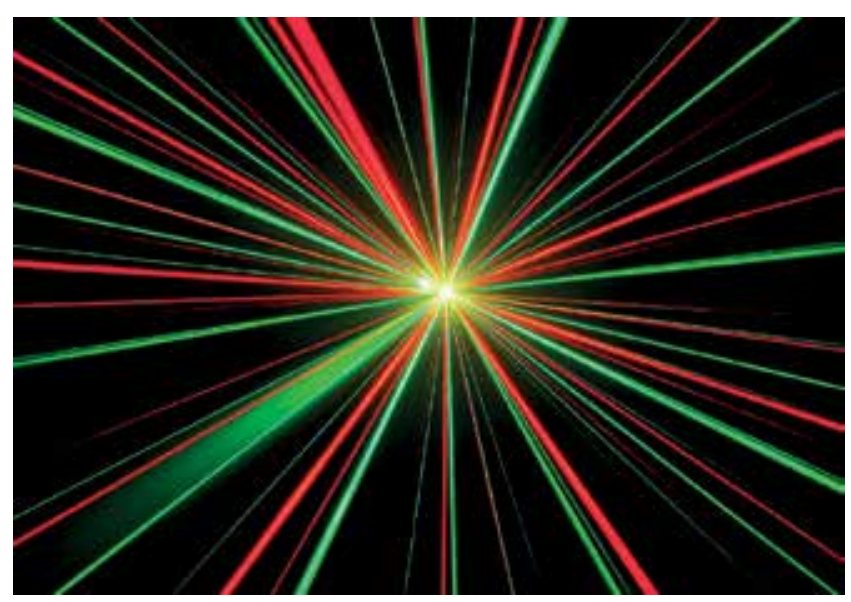

cations and other tools to achieve those objectives are investigated, such as the use of phototherapy, particularly laser and its variables.

The experimental model of induced tooth movement developed by Henler and Nanda ${ }^{13}$ is the one most frequently used worldwide to evaluate the effect of several factors associated with orthodontic clinical practice, and was revised by Ren et al. ${ }^{21}$ in 2004. In 2009, Fracalossi et $\mathrm{al}^{6}$ suggested a standardization of cross-sectional cuts of murine molars for the analysis of phenomena associated with induced tooth movement, and Santamaria $\mathrm{Jr}^{22}$ described a practical way to quantify it. Still in 2009, Maldonado ${ }^{19}$ investigated the effect of medications, particularly analgesic and anti-inflammatory drugs, on induced tooth movement and the frequency and severity of associated induced tooth movement.

The use of phototherapy, particularly laser light therapy, in induced tooth movement has raised the interest of clinicians and researchers. In 2013, Vasconcelos, ${ }^{25}$ in his doctorate thesis, found that the use of lower level laser did not affect root resorption induced by orthodontic treatment.

However, using different methods, the effect of phototherapy still requires further experimental investigation due to its many variables, as suggested by reading the main studies published about this topic. $1,3,4,5,7-12,14-18,20,23-26$

We describe four fundamental points for experimental models to ensure that the evaluation of the effects of medication and phototherapy on induced tooth movement and associated root resorption is free of external influence.

\section{THE FOUR FUNDAMENTAL POINTS IN THE CONCEPTION AND DESIGN \\ OF AN EXPERIMENTAL MODEL}

Several experimental studies about this topic have not described whether they followed these four fundamental points during study design, planning, method choice and discussion of results:

1. Cementoblast death. During tooth movement, the root is protected against inflammatory tooth resorption by cementoblasts, which do not have receptors for mediators that interfere with bone remodeling.

If the objective of a study is to investigate the effect of medications or phototherapy on the frequency and severity of root resorption, the forces of the experimental model should effectively and confirmedly produce lesions on the cementoblast layer, thus eliminating this root protection. The lesion on this layer, and the consequent death of cementoblasts, is the key phenomenon to initiate inflammatory root resorption.

If the experimental model, randomly and in an uncontrolled way, does not ensure that cementoblasts will die in all animals, results about the protective effect of a medication or phototherapy may be compromised. Teeth with preserved cementoblasts does not undergo inflammatory tooth resorption with or without the application of medication or phototherapy.

2. The preservation of cementoblasts. During desired, ideal and normal induced tooth movement, cementoblasts should be preserved.

Cell stress and inflammation of the periodontal ligament should not affect cementoblasts during orthodontic movement. The forces applied should not result in the death of cementoblasts when the objective is to test the optimization of tooth movement by means of medication or phototherapy.

Medications and phototherapy does not increase or decrease cementoblast resistance to anoxia induced by the compression of periodontal blood vessels during orthodontic movement. When there is direct and excessive compression of periodontal structures, or even when the tooth being moved applies force to the alveolar bone, medications and phototherapy does not avoid the death of cementoblasts.

When medications and phototherapy are tested to optimize tooth movement and shorten treatment time, the experimental model, as well as the intensity and concentration of forces, should effectively preserve the 
integrity of the cementoblasts layer. Excessive force induces hyalinization of the periodontal ligament and root resorption, which are not part of the desired optimization, that is, tooth movement without collateral damage to periodontal and root tissues.

3. Applications should be blinded. The phototherapy (laser, for example) operator, as well as the operator that places appliances for tooth movement, should not know which animals will effectively receive the test treatment. Applications should be performed using identical devices; for example, a unit that applies light and the other that does not, but that is a perfect imitation of a laser unit.

Likewise, the person that administer medications, as well as the operator that places the appliances for tooth movement, should not know whether they are administering or not the test drug or a placebo to the animals. The control group should equally receive a mock liquid medication or tablet so that the persons that administer the medication and feed the animals do not know which animals are in the experimental group.

Only at the end of the experiments should the specimens be identified, grouped and separated according to experimental conditions to which they were submitted, so that there is no other influence than the experimental variable under evaluation.

4. Examiners should not know what animal received or not the test. As the specimens are prepared for CT or microscopic analysis, the pathologist or radiologist should not know which specimens are in the control or experimental group. Random examination of each specimen, not separated into groups, should be conducted according to previously established criteria. Examiners should be free of any type of influence when they start examining each specimen separately.

Specimens should be identified, grouped, separated and compared only after the results are recorded. Therefore, only the variable under test will justify or not the differences found.

\section{FINAL CONSIDERATIONS}

The use of medications and phototherapy in orthodontic movement should be evaluated carefully and free of interests of any nature, particularly commercial interests. To ensure that the environment is rigorously controlled and free of influences, such as those due to human subjectivity, we described four fundamental points that should characterize any study that uses experimental models of induced tooth movement and associated root resorption:

1. Cementoblast death. If the objective is to check the effect on root resorption, the forces experimentally applied must produce a lesion on the cementoblast layer of all specimens.

2. The preservation of cementoblasts. If the objective is to optimize induced tooth movement and reduce treatment time without side effects, the forces experimentally applied should not injure the cementoblast layer of any specimen.

3. Applications should be blinded. The person applying phototherapy or administering medication and the operator that places appliances should not know which animals will effectively receive the test treatment, and specimens in the control group should receive mock treatments.

4. Evaluators should not know what animal received or not the test. CT and microscopic analysis of the specimens should be random, and the group to which the specimen belongs should not be identified, to ensure that radiologists and pathologists are not affected in their evaluation of phenomena.

These measures will ensure that results are free of subjective influences from investigators and, at the same time, are more reliable and easier to extrapolate to clinical orthodontic practice. 


\section{REFERENCES}

1. Altan BA, Sokucu O, Ozkut MM, Inan S. Metrical and histological investigation of the effects of low level therapy on orthodontic tooth movement. Laser Med Sci. 2012;27(1):131-40.

2. Consolaro A. Reabsorções dentárias nas especialidades clínicas. 3a ed Maringá: Dental Press; 2012.

3. Cruz DR, Kohara EK, Ribeiro MS, Wetter NU. Effects of low-intensity laser therapy on the orthodontic movement velocity of human teeth: a preliminary study. Lasers Surg Med. 2004;35(2):117-20

4. Doshi-Mehta G, Bhad-Patil WA. Efficacy of low-intensity laser therapy in reducing treatment time and orthodontic pain: a clinical investigation. Am J Orthod Dentofacial Orthop. 2012;141(3):289-97.

5. Fonseca PD, Lima FM, Higashi DT, Koyama DF, Toginho Filho D de O, Dias IF, et al. Effects of light emitting diode (LED) therapy at $940 \mathrm{~nm}$ on inflammatory root resorption in rats. Lasers Med Sci. 2013;28(1):49-55.

6. Fracalossi ACC, Santamaria Jr M, Consolaro MFMO, Consolaro A. Movimentação dentária experimental em murinos: periodo de observação e plano dos cortes microscópicos. Rev Dental Press Ortod Ortop Facial. 2009;14(1):143-57.

7. Gama K, Habib FA, Monteiro JS, Paraguassú GM, Araújo TM, Cangussú $M C$, et al. Tooth movement after infrared laser phototherapy: clinical study in rodents. Photomed Laser Surg. 2010:28(suppl 2):S79-83.

8. Genc G, Kocadereli I, Tasar F, Kilinc K, El S, Sarkarati B. Effect of low-level laser therapy (LLLT) on orthodontic tooth movement. Lasers Med Sci. 2012;27(2):49-57.

9. Genovese MD, Olivi G. Use of laser technology in orthodontics: hard and soft tissue laser treatments. Eur J Paediatr Dent. 2010;11(1):44-8.

10. Goulart CS, Nouer PR, Mouramartins L, Garbin IU, Lizarelli R FZ. Photoradiation and orthodontic movement: experimental study with canines. Photomed Laser Surg. 2006:24(2):192-6

11. Habib FA, Gama SK, Ramalho LM, Cangussú MC, dos Santos Neto FP, Lacerda JA, et al. Effect of laser phototherapy on the hyalinization following orthodontic tooth movement in rats. Photomed Laser Surg. 2012;30(3):179-85

12. Habib FA, Gama SK, Ramalho LM, Cangussú MC, Santos Neto FP, Lacerda JA, et al. Laser-induced alveolar bone changes during orthodontic movement: a histological study on rodents. Photomed Laser Surg. 2010;28(6):823-30.

13. Heller IJ, Nanda R. Effect of metabolic alteration of periodontal fibers on orthodontic tooth movement. Am J Orthod. 1979;75(3):239-58.
14. Kawasaki K, Shimuzi N. Effects of low-energy laser irradiation on bone remodeling during experimental tooth movement in rats. Lasers Surg Med. 2000:26(3):282-91

15. Kim SJ, Kang YG, Park JH, Kim EC, Park YG. Effects of low-intensity laser therapy on periodontal tissue remodeling during relapse and retention of orthodontically moved teeth. Lasers Med Sci. 2012;28(1):325-33.

16. Kim SJ, Paek JH, Park KH, Kang SG, Park YG. Laser-aided circumferential supracrestal fiberotomy and low-level laser therapy effects on relapse of rotated teeth in beagles. Angle Orthod. 2010;80(2):385-90.

17. Limpanichkul W, Godfrey K, Srisuk N, Rattanayatikul C. Effects of lowlevel laser therapy on the rate of orthodontic tooth movement. Orthod Craniofac Res. 2006:9(1):38-43.

18. Liu Z, Xu J, Lingling E, Wang D. Ultrasound enhances the healing of orthodontically induced root resorption in rats. Angle Orthod. 2012;82(1):48-55

19. Maldonado VB. Efeitos microscópicos do ácido acetilsalicílico (aspirina) e do acetaminofeno (Tylenol) na movimentação dentária induzida e nas reabsorções radiculares associadas [dissertação]. Ribeirão Preto (SP): Universidade de São Paulo; 2009

20. Marquezan M, Bolognese AM, Araújo MT. Effects of two low-intensity laser therapy protocol on experimental tooth movement. Photomed Laser Surg. 2010;28(6):757-62.

21. Ren Y, Maltha JC, Kuijpers-Jagtman AM. The rat as a model for orthodontic tooth movement: a critical review and a proposed solution Eur J Orthod. 2004:26(5):483-90.

22. Santamaria Jr M. Biologia da movimentação dentária induzida e das reabsorções radiculares: influência do gênero e dos bisfosfonatos [tese]. Bauru (SP): Universidade de São Paulo; 2009

23. Seifi M, Shafeei HA, Daneshdoost S, Mir M. Effects of two types of lowlevel laser wave lengths (850 and $630 \mathrm{~nm}$ ) on the orthodontic tooth movements in rabbits. Lasers Med Sci. 2007:22(4):261-4.

24. Sousa MV, Scanavini MA, Sannomiya EK, Velasco LG, Angelieri F. Influence of low-level laser on the speed of orthodontic movement. Photomed Laser Surg. 2011:29(3):191-6.

25. Vasconcelos EC. Estudo histomorfométrico da ação do laser de baixa potência na reabsorção radicular ortodonticamente induzida em ratos [tese]. Bauru (SP): Universidade de São Paulo; 2013.

26. Yossef M, Ashkar S, Hamade E, Gutknecht N, Lampert F, Mir M. The effect of low-level laser therapy during orthodontic movement: a preliminary study. Lasers Med Sci. 2008:23(1):27-33. 